\title{
Montage as the Meaning-generative Principle of Avant-garde: From Montage in Cinema to Montage in Theatre (Soviet and Post-Soviet Theatre and Cinema)
}

\section{Lilia Nemchenko}

Liberal Arts University, Ekaterinburg, Russia

\section{Abstract}

The principle of montage was a discovery of the avant-garde that is still widely used in modern culture. The article discusses how montage from a technique applied in early cinematography came to play a crucial role in organization of various texts produced

Corresponding Author: Lilia Nemchenko

I.m.nemchenko@urfu.ru

Received: 26 April 2018 Accepted: 25 May 2018 Published: 7 June 2018

Publishing services provided by Knowledge

(c) Lilia Nemchenko. This article is distributed under the terms of the Creative Commons

Attribution License, which permits unrestricted use and redistribution provided that the original author and source are credited.

Selection and Peer-review under the responsibility of the ISPS Convention 2017 Conference Committee.

\section{G OPEN ACCESS}

by different arts, in particular, theatre. The avant-garde art strove to transform daily life and the montage principle was inextricably linked to these value orientations. This research analyzes the potential of montage as a meaning-generative mechanism in avant-garde films and theatre performances in the 1920 s and 1930s. This principle gained significance for theatre in the second half of the twentieth and the early twenty-first century. The article investigates the connections between Soviet avantgarde theatre and cinema and explores the reasons why the interest to the montage principle was revived in Yury Lubimov's theatre and in the post-dramatic theatre of Dmitry Krymov.

Keywords: avant-garde; montage; postdrama; Dziga Vertov; Vsevolod Meyerhold; Dmitry Krymov; Yury Lubimov; Sergey Eisenstein

\section{Introduction}

Cinematographic theory and practice in experiments of Lev Kuleshov, D.W.Griffith, Sergey Eisenstein, and Dziga Vertov established the status and the distinctive identity of the cinema as an art, with montage as its dominant element.

The language of cinema evolved in the context of the avant-garde, which sought to actively integrate art into daily life and to transform social reality. The first montage theories pointed out that it was possible to distinguish between montage ('assembling' in French) in its particular meaning as the process of glueing individual pieces 
of footage together and montage in its more general meaning. In the latter case, montage turned out to have existed long before the invention of cinema (bricolage in the primeval period; fragmentation in the nineteenth-century literature). Moreover, it was used by other arts: for example, collage in Cubism and Constructivist photography. In his theory of montage, Sergey Eisenstein identified the predecessors of this method in other art forms, such as painting, poetry, Meyerhold's theory of bio-mechanics, and hieroglyphics. In fact, Eisenstein's 'montage of attractions' was born while he was searching for the 'new theatre', which later came to be known as cinematography.

The montage principle means that elements are first shown as discrete and then are assembled to create a composite whole. This principle was discovered by the avantgarde in Soviet and post-Soviet art, in particular theatre. This principle played the key role in creating a new, unusual way of looking at the world (things, events, history) in the $1960 \mathrm{~s}, 1970 \mathrm{~s}$ and in the $2000 \mathrm{~s}$. In the first case, the montage principle reflected the practice of resisting the official Soviet culture (Yury Lubimov) and in the second, the practice of deconstructing clichés of mass culture, including the Soviet classic (Dmitry Krymov).

\section{Cinematography in the Context of Avant-garde}

The development of cinema as a new kind of art chronologically coincided with the experimentation and discoveries of the avant-garde epoch. Early cinema relied on the preceding culture of realism oriented towards factuality, objectivity and cognition. It was also directly connected with the results of the industrial-technological revolution, which brought about such technological advances as the photo- and then video-camera. As Walter Benjamin wrote, 'around 1900, technological reproduction not only had reached a standard that permitted it to reproduce all known world of art, profoundly modifying their effect, but it also had captured a place of its own among the artistic processes. In gauging this standard, we would do well to study the impact which its two different manifestations - the reproduction of artworks and the art of film - are having on art in its traditional form' ([2], 20). Cinema was inextricably linked to orientations of bourgeois culture, which engendered new forms of entertainment [21].

In the early twentieth century, the question about whether cinema belonged to the domain of art or not was still debatable. Cinema was seen as a means of documenting reality, and its creators - the Lumiere Brothers - saw their invention as a way of recording events. Yury Lotman observed that 'Lumiere's way of thinking was similar 
to that of a scientist rather than that of an inventor. What he valued most in the cinematography was the photographic recording of movement while the result - synthesis of movement on the screen - considered to be no more than an insignificant trick, a tribute to commercial sensation. The Lumiere Brothers believed that this sensation would be short-lived' ([17], 44). It did not take long before cinema turned into a means of creating new reality, which did not only reflect real life but also created images of its own. Georges Méliès, who created the first science fiction film, discovered yet another possibility by combining the advances in film technology with theatrical arts and the art of optical illusion. In the case of Méliès, however, the director did not reject the theatrical conventions and hardly ever resorted to location shooting but instead used a change of perspective. Although Méliès used the stop-motion effect in his films, they give an impression of being theatrically staged.

Olga Burenina-Petrova believes that 'Méliès was the first in the history of art to combine the theatre or circus stage with the screen, thus highlighting the fundamental similarity in the nature of circus and cinema' [4].

Early films were orientated towards movement-based arts due to cinema's ability to capture motion and, therefore, time (for example, a dance or a circus trick or even a literary plot). In this respect, the early stage of cinema development (1900s and 1910s) corresponded to figurative, mimetic art, which used linear time and static space (like in the actor-manager's theatre). Together with the pellucid plot, these were sufficient to construct artistic reality. For instance, Evgeny Bauer's melodramas, which were popular in the early twentieth century, reflected the Art Nouveau style with its contemplative beauty, exquisite ornamentation, and stylized forms.

The fact that cinema emerged so late in the system of artistic culture made it more susceptible to the spirit of the avant-garde and its principles. It was easy for cinematography to follow the avant-garde's desire to break away from the past since for the cinema there was virtually no past. In cinematography, the past was understood as, first, the emerging tradition of consecutive, linear narrative and, second, reliance on artistic and performance traditions of other arts such as theatre, literature, visual arts, and so on.

One of the fathers of the French avant-garde cinema Marcel L'Herbier described the prospects of cinema development the following way: 'Up until today, a toy, but tomorrow, an excellent instrument in the hands of future democrats, cinematography must cognize itself and purge itself from the past for the sake of the future' $([25], 38)$.

D.W.Griffith is known to be the first film director to create his own language while remaining within the boundaries of narrative genre cinematography. Griffith was 
inspired by Charles Dickens' novels: in the 1910s, he discovered the cinematic possibilities of turning a linear, homophonic narrative into a polyphonic one with the help of parallel and cross-cutting editing, which is the process of alternating different plot lines and actions occurring at the same time but in different places. It should be noted that in the early twentieth century, the Pathé studio was already using parallel montage for comedies to show different actions happening in different locations simultaneously (in literature this effect was usually created by using the word 'meanwhile'). Griffith started using montage not only for plot development but mostly for portraying dramatic action, eliciting emotional response in the viewers. In other words, Griffith was the first to discover performativity of cinematic images.

He demonstrated how to build up the audience's tension and how to manage it through balancing shot variations, episodes, and the setting in the overall film structure. Eisenstein called Griffith's discoveries 'a secret of the structure of an emotional language': '...for the very principle of montage, as is the entire individuality of its formation, is the substance of an exact copy of the language of excited emotional speech... but in inner speech, where the affective structure functions in an even more full and pure form' $([8], 186)$. As Deleuze pointed out, 'if we give to Griffith the distinction, not of having invented montage, but of having raised it to the level of a specific dimension... Griffith conceived of the composition of movement-images as an organisation, an organism, a great organic unity. The organism is, firstly, unity in diversity, that is, a set of differentiated parts; there are men and women, rich and poor, town and country, North and South, interiors and exteriors, etc. These parts are taken in binary relationships which constitute a parallel alternate montage, the image of one part succeeding another according to a rhythm' ([7], 75).

The montage principle of organization corresponded to yet another pivotal principle of the avant-garde - the critique of mimesis and the Aristotelian understanding of art as an imitation of life. Both avant-garde theoreticians and practitioners (Vasily Kandinsky, Kazimir Malevich, Pablo Picasso, and others) resented the concept of mimesis. Malevich wrote: 'Intuition leads our will to the basis of creation but in order to reach it it is essential to free oneself from the objective and to create new signs, leaving the new arts of photography and cinematography to worry about objectivity' [19]. Critique of traditional mimesis was realized through non-objective or abstract films. Strictly speaking, it was the beginning of the avant-garde in the cinema, more specifically, the French avant-garde of the 1920s, in which, as P.Bagrov puts it, 'for the first time in the world - with a few exceptions - the story (sujet) started to differ from the plot 
(fabula). This was achieved through the rich imagery and the specific rhythmical montage' [1]. Jean Epstein in his manifesto 'Senses' wrote the following: 'No painting. The danger of tableaux vivants in contrasting black and white. Images for a magic lantern. Impressionistic corpses. No texts. The true film does without... But the supernatural, yes. The cinema is essentially supernatural' ([12], 80).

Fernand Léger assembled objects and cogged wheels to create forms that did not exist in reality but it was not these forms that played the central part but the montagegenerated rhythm. 'The error in painting is the sujet (story). The error in cinema is the scenario. Freed from this burden, the cinema can become a giant microscope of things that have never been seen or experienced before' $([27], 76)$.

Thus, in cinema, the avant-garde applies montage techniques not only to transcend the linearity of the plot. In the absence of a mimetic story/scenario, montage turns into a meaning-generative principle for organization of space and time: following the director's will, separate fragments of the whole are assembled into a new object, which the director consciously models on the basis of associations and qualities shared by different objects and thus uniting these objects into one integral picture of the world. It can be supposed that montage cinematography creates its own 'new, critical understanding of mimesis' $([15], 14)$. 'This new whole consists of separate identifiable fragments, therefore, 'montage can be described as a new type of mimesis...' ([15], 14).

Andrey Fomenko in his research of the avant-garde has pointed out that 'montage turned into an original 'style' of thinking of the avant-garde artists of the 1920s. The essence of this style is that the work of art is understood as a complex of components separated by intervals preventing them from merging into one homogeneous whole' $([13], 23)$. Obstacles to the integration of components are intentionally constructed by the author with the help of 'junctions between various elements of the painting' ([15], 16). These obstacles prevent the viewer from perceiving the whole image, that is, they make him think in contrasts or paradoxes.

\section{Montage in Soviet Avant-garde Cinema and Theatre}

Soviet avant-gardists used montage not only for organizing the reality in their films but also to convey ideological meanings. For example, Eisenstein, having studied the theory and practice of Griffith's montage, accused him of the bourgeois spirit. By this he meant that in Griffith's films the author pointed out the oppositions but failed to show them in their dialectical struggle or, in other words, allowed the audience 
to empathize but prevented them from becoming politically active. Such meditative reflection was grounded in the classical model of Kant's aesthetics and its principle of disinterestedness. For the avant-garde, however, the situation in which the viewer watches, recognizes and empathizes seems to be insufficient; the avant-garde sought to overcome autonomization of art and to achieve convergence of art and life. Peter Bürger explains the principle of 'effectiveness' of art the following way: '... When the avant-gardists demand that art become practical once again, they do not mean that the contents of works of art should be socially significant. The demand is not raised at the level of the contents of individual works. Rather, it directs itself to the way art functions in society, a process that does as much to determine the effect that works have as does the particular content... The avant-gardists proposed the sublation of art - sublation in the Hegelian sense of the term: art was not to be simply destroyed, but transferred to the praxis of life where it would be preserved, albeit in a changed form...' $([5], 9)$. Mark Shapir wrote the following about the 'pragmatics of action' of the avantgarde: 'In the avant-garde art, pragmatics comes to the forefront. The effectiveness of art comes to the fore - art aims to impress, awaken the audience, provoke their active reaction' $([24], 5)$.

The rhetoric of rejecting the old contemplative art combined with the new understanding of art as pragmatic action can be found, apart from a few exceptions, in all avant-garde manifestos. Pragmatics of the avant-garde in cinema largely relies on montage or assembly of heterogeneous discrete elements (shots, close-ups, captions) into one integral whole, when ordinary, customary material such as a factory in Eisenstein's film or a hairdresser's in Vertov's were presented not as objects for passive contemplation and recognition but were aimed at provoking an active reaction - emotional, mental, volitional. Thus, contemplation was replaced by the feeling of astonishment and shock, which led people to question how just this social reality was. Sergey Eisenstein referred to such unexpected and non-trivial reactions as 'attraction'.

Dziga Vertov denounced old art, in particular narrative films, and replaced them with chronicles. In the manifesto of his new artists' group 'Kinoks', Vertov described the principles of effective art, in which the chronicle was to become a work of dramatic, comic or tragic art by means of montage (organization of the visible world). According to both Western and Soviet avant-gardists, machine played a central role in building of the new world while the art of cinema was a result of the technical process. In this process, montage primarily performed technical functions but the avant-garde also used it to generate new meanings. 
According to Vertov, the aim of the artist is to reveal association of the man with the machine, show their similarity, isomorphism of the natural, social and cultural, which is possible only through montage.

The Kinoks' principles were most fully realized in Vertov's film 'The Man with a Movie Camera' (1929). The director himself maintained that this film was to be treated both as 'a practical result but also as a theoretical manifestation on the screen' ([26], 109). This film sought to create a new international language of cinema and demonstrate the emergence of the new world and the new personality. Despite the principle of 'life caught unawares', it actually was the result of constructing reality through various types of montage (parallel, cross-cutting, associative, and intra-shot) ([25], 79). The artist makes life more ordered and rational; the 'man with a movie camera', like a demiurge, creates a beautiful new world. Vertov wrote: 'From one person I take the hands, the strongest and most dexterous; from another I take the legs, the swiftest and shapeliest; from the third, the most beautiful and expressive head - and through montage I create a new, perfect man' $([26], 55)$. The film uses recurring shots of the film-editing table, hands of the woman pulling a strip of film off the reel, editor's shelves with rolls labelled 'Market', 'Factory', 'Leisure', and so on. Vertov demonstrates the creation of a 'montage' person by alternating close-ups showing the face and hands of a packer, telephone operator, miner, plasterer, and so on. Thus, images of people are created through close-ups of their face and hands ([25], 82), which resembles Meyerhold's principle of biomechanics which required that the actor on stage should be likened to a mechanism or a machine - the sum of their body and the will of the director.

Although 'The Man with a Movie Camera' was made without subtitles, in the previous films Vertov used not only people and objects but also Alexander Rodchenko's animated titling. In 'Leninist Cine-Pravda', devoted to the anniversary of Lenin's death, Vertov enhanced the tragic feeling by combining images of the living and the dead, movement interspersed by moments of stillness as if all movement was stopped by the overwhelming and absolute grief. The state of grief was constructed through the contradiction between the image of the man who was 'more alive than all the living' and the blackness of the screen, in which life ceased to exist and turned into letters of the subtitles.

Vertov demonstrated that the combination of shots made montage a means of creating new reality, in which the chronicle was no longer independent of the director's eye but was transformed into a material for creating a new reality and a new person. 
Eisenstein disagreed with Vertov on the role of chronicle in cinema but used montage techniques by introducing subtitling in his 'Strike' and 'Battleship Potemkin'. Thus, Eisenstein did not work with the chronicle form directly but always presented film reality as a chronicle. Vertov, in his turn, criticized Eisenstein for borrowing formal elements of the 'cine-eye' to create illusions, which distorted their true nature. A film director creates illusions but illusions are necessary only to the historically doomed bourgeois spectator while workers and peasants wanted to see real life on the screen - at least in places where 'the poison had not yet penetrated deeply and where people had not got addicted to the poisonous sweetness of melodramas' [23]. Vertov, who accused Eisenstein of voluntarism, himself often became an object of criticism not only in the USSR but also abroad, as John MacKay points out in his article: 'Indeed, Vertov's reputation outside the Soviet Union between C. 1937 and 1960 was not simply that of a partisan defender of non-fiction against fiction, but that of a dogmatic and often naive celebrant of this supposed "objectivity," and hence epistemological superiority, of the camera and what it registers' [18]. Dziga Vertov discovered the expressive, conceptual potential of montage, which inspired filmmakers to use it not only in the documentaries but also in fiction films.

While Vertov's innovation stemmed from the very nature of cinema, Eisenstein came to cinema from theatre, like Leningrad directors of FEKS group. According to O.Bulgakova, in theatre, montage was understood in two ways: 'on the one hand, it was the understanding of montage that coincided with that of the Constructivists, who applied the concept of construction to any artistic phenomenon (only the material and the technique of 'glueing' together separate pieces were different and depended on the sphere of application) and saw this construction as a complex of separate architectural elements, episodes of drama or fragments of the film tape. On the other hand, theatre adopted the cinematographic understanding of montage as a narrative with multiple parallel plot lines. From this point of view, there was no significant difference between theatre montage and cinema montage' (Bulgakova 1988, 99).

The montage principle of organization (spatial and temporal) was realized in the context of Regietheater (director's theater), which problematized the relationship between the literary source and the adaptation and thus, instead of being merely a translator of the dramatic text, the director turned into a reader, narrator, literary critic, artist and organizer of the communication with the audience.

The literary experiments tended to be associated not only with the interpretation of the literary source, but also with the new approach to theatrical performance as a spectacle created according to the laws of technical production, capable of organizing 
people and affecting the minds of the viewers. Montage revealed discreteness of events and the fragmented nature of the world and was thus seen as effective artistic means. It was not by chance that innovative theatre directors Kosintsev, Trauberg and Eisenstein, who later turned to cinematic art, were also interested in circus, vaudeville and music-hall. These artistic practices were non-narrative and constructed works of art by relying not so much on the thematic as on the rhythmic principle. As Eisenstein put it, 'cinema is the contemporary stage of theatre. The next, consecutive phase' ([8], 281).

Like other avant-gardists, FEKS artists were interested in the rhythm, dynamic, technique and art that could directly affect the public. Grigory Kozinstev in FEKS manifesto (The Factory of the Eccentric Actor) wrote the following: 'Today - a Signal. To the Machines! Belts, chains, wheels, hands, feet, electricity. The rhythm of production. Yesterday - Museums, Temples, Libraries. Today - Factories, Workshops, Dockyards...The pace today. The rhythm of the machine concentrated by America, realized on the street. Second. Art without a capital letter, a pedestal or a fig leaf. Life requires art that is hyperbolically crude, stupendous, nerve wracking, openly utilitarian, mechanicallyprecise, momentary, rapid. Otherwise no one will hear, no one will see, no one will stop. Everything adds up to this: the art of the twentieth century, the art of 1922, the art of this very moment - eccentricism. We are eccentricism in action. A spectacle-should beat rhythmically on the nerves... The basis of this - continuous transformation. Sirens, shots, typewriters are eccentric music. Tap shoes - the start of a new rhythm...' [1].

Theatre montage always strove to eliminate the narrative dramatic continuum and break the performance into a sequence of episodes, which created a dotted, syncopic rhythm and, therefore, 'it became possible to make breaks, segments, new combinations and to move between the foreground, medium ground and background, between the aesthetic reality and extra-aesthetic reality. The principle of material organization relies on establishing dynamic connections between the foreground, medium ground and background and sudden switches of action between them' (Bulgakova 1988, 103).

Eisenstein, who studied the principles of biomechanics at Meyerhold's State School for Stage Direction, sought to construct such a movement that did not depend on the 'sincerity' of the actor's movement but on his or her 'imitative, mimical infectiousness'. Meyerhold's logic of plot development did not have a linear narrative structure, like in traditional theatre, but on the rhythm and pace of separate parts and episodes which the plays consisted of ('The Government Inspector', 'Woe from Wit' and others). Meyerhold created fragmented space similar to cinematic montage, in which different parts of the stage were 'opened' in accordance with the light plot and the musical rhythm 
of the performance. If all parts of the stage were lit, the foreground, middle ground and foreground produced one general picture. Meyerhold rejected traditional theatre setting, preferring non-figurative Constructivist setting (stage as a workbench), which allowed the audience to focus on actors' bodies as generators of energy.

Eisenstein abandoned his career in theatre because he could not overcome the dominant position of the actor in a theatre performance. After staging 'The Wise Man', Eisenstein observed that no matter where he placed or hid the actor, the actor's body attracted the audience's attention. Thus, cinema was to become the new theatre, in which the actor would no longer dominate but would be a part of the whole aimed at galvanizing the audience's perception.

For example, in Eisenstein's first film 'Strike' (1924), montage played the central role, being the organizing principle and a technique at the same time. Violence coming from the outside world (police, administration, dispersal of the rally) was shown through the violent energy of the montage which was to incite rage and protest in the audience. From the slow, almost epic narrative about the factory, the pace accelerates until it reaches the scene of mass shooting, when the shots with people falling on the ground alternate with those showing cattle being slaughtered. After filming 'Strike', Eisenstein contended that montage was 'the way of completely freeing the theatre from the weight of "illusory imitativeness" and "representationality", which up until now has been definitive, inevitable, and solely possible' $([10,11], 339)$.

For Eisenstein, cinema was primarily 'a factor for exercising emotional influence over the masses' (Eisenstein, 379). Therefore, as a director, especially in his early films, he focused on pragmatics of artistic expression. Montage 'provided a way to produce a brutal and shocking effect, make the audience hypersensitive to the agitation and stimulate the audience's psychological identification with the action on the screen' ([20], 323).

Working on his 'montage of attractions', Eisenstein discovered the potential of associative montage to elicit the spectator's emotional response. He believed that the montage principle was found on all structural levels of the creative process: starting from the author's original idea to the work itself and then to the audience's perception. 'The strength of montage resides in this, that is, includes in the creative process the emotions and mind of the spectator. The spectator is compelled to proceed along that selfsame creative road that the author travelled in creating the image' $([10,11]$, 441). Eisenstein puts himself in his spectator's shoes and breaks down into separate shots Leonardo da Vinci's paintings, Serov's portrait of Ermolova, Pushkin's 'Poltava', 
Dostoevsky's 'Karamazov Brothers', and so on. Eisenstein also discusses the montage principle as a way to organize a theatrical performance and actors' work on their roles.

\section{Montage Principle in the Soviet Theatre in the Second Half of the $20^{t h}$ and the Early $21^{\text {st }}$ Century}

Avant-garde experimentation in the 1920 s was naturally connected to the avantgardists' ideas about the purpose of art and its social effectiveness. At later stages, authors drew upon avant-gardist traditions, in particular the montage principle of text organization, when they needed to overcome the stereotypes of flippant attitude to art as entertainment or illustration. Therefore, the interest of Yury Lubimov, who created his own variant of Soviet political theatre, in Bertold Brecht's philosophy seems quite natural. In his anti-bourgeois theatre Brecht resorted to the montage principle developed in the 1920s. The montage principle aimed at provocative combination of unusual elements and was used by Brecht to deliberately evoke the feeling of discomfort in the audience: Brecht intentionally replaced the principle 'make it beautiful for us' with that of 'we shall make you feel uneasy'. Brecht's alienation effect performed the same functions as Eisenstein's montage, that is, provoked a strong political feeling of anger and rejection of the situation described in the parable. Since Brecht's montage is analytical, it accentuates the logic behind the director's thinking and intensifies the audience's perception by openly didactic means.

Yury Lubimov, who on multiple occasions expressed his philosophical and aesthetic indebtedness to Brecht, also uses the principle of montage. In Lubimov's interpretation, the montage principle manifested itself on all levels of the text - starting from the division of the play into episodes, the usage of long shots and close-ups in positioning, counterpoint, and to orchestrating the audience's emotions. In one of the early performances of Moscow Theatre on Taganka 'Listen!', the story was narrated by four impersonations of Vladimir Mayakovsky. The image of the poet was divided into separate stages of his life and the topics that interested him in certain periods. Other characters included large cubes with letters which were used by the actors to put together famous quotes from Mayakovsky's poems. These letters also served as distress signals when the inspection board came to 'close' the play 'Mystery Bouffe': the letter ' $B$ ' was cut off and what was left sounded like 'Mystery Ouffe!' (sounding like the Russian equivalent to 'Psht!') 
The director usually combines parts of the performance by applying the montage principle to contrast consecutive episodes and by using short scenes similar to Eisenstein's 'montage of attractions'. Lubimov uses montage to create the polyphony of voices. He often introduces quotes and works of other writers into the original drama: for instance, songs in 'The Good Person of Szechwan' included poems by Marina Tsvetaeva and Boris Slutsky while 'Life of Galileo' showed two Brecht's versions of the finale scene. However, unlike Brecht's logic of montage, Lubimov mostly relied on associative montage that provoked dialogue with the audience and affirmed everybody's right to speak and be heard. In the 1960 s and the early 1970s, the montage principle was used to 'demonstrate resistance to violence that the government justified by historical reasons' ([15], 43).

The montage principle can also be found in Dmitry Krymov's theatrical performances. His theatre relied on the collage techniques developed by the avant-garde in the early twentieth century. Krymov's theatre is performative in the sense that it does not depend on words and that its dramatic personae are played not only by actors but by the world of objects that take on life of their own through the power of the director's imagination. By following the ever changing fragments, the spectator finds himself in the space of historical and cultural associations and contexts constituting the director's artistic mind.

Krymov works with classical texts (literature and visual arts) that turned into catch phrases disseminated by the modern mass media and mass culture. In his performances 'Eugene Onegin. In Their Own Words', 'Gorki-10', and in 'Gogol. "The Dead Souls". The Story of a Present', the director deconstructs stereotypical representations of classical literature in the form of quotes and visual images.

His performance 'Opus № 7 ' consists of two parts which are seemingly unrelated to each other - 'Genealogy' and 'Shostakovich'. Lev Rubinstein, the author of 'Genealogy', wrote forty-two sentences, the first starting with: 'Abraham gave birth to Isaac...', and the forty-second, 'the time came for the baby to be born...Jesus Christ'. These phrases connect the Old and New Testament and the generations of beautiful Biblical men, who, after being born from the light of the movie projector, would retreat into crematorium ovens, taking away with them baby prams, toy balls, gaberdines, their art of tailors, watchmakers, tinkers, and so on.

It is not just 'a generation goes and a generation comes' kind of story but the history of the twentieth century that realized and finished many projects, one of which was the extermination of the Eastern European Jews and their world of communities and artisans, now found only in photographs. One of the culmination points of the 
performance is the montage of photographs, which differ in size, image quality, and purpose. This book of memory includes tremendous two-meter portraits and unassuming album pictures, professional and amateur works, and even X-rays shots. Along with the photographs, other signs of memory such as fragments of letters, instructions, and notes are pouring out of the Wailing Wall and, like a snowstorm, fill the space between the Wall and the audience, which makes the spectators blink involuntarily and after the performance shake off tiny pieces of paper from their clothes. Thus, the audience is left face to face with history, which you are always tempted to brush aside as something that is bothering you with strange ancestral names. Actors and spectators are caught inside the force field of the past, which is not presented as mystical or enigmatic but as something visible and tangible, for example, as old things which have lost their owners. This surrealist dance, which one cannot escape from, takes place within the open space, unlimited by the stage, and the audience has to follow the fast rhythm of images, which is sometimes difficult to keep up with, so certain shots are missed, which is done intentionally because it is impossible to capture the flow of life, since 'everything is futile, a chasing after the wind'. One government replaces another, a German soldier's boot sends a baby pram flying across the screen, the life in the film turns into reality, while the screen is crossed by another pair of boots and another field jacket, and yet another profile with the pince-nez glasses of Lavrenty Beria.

The baby pram (a powerful shot, 'attraction' from Eisenstein's 'Battleship Potemkin'), which at the beginning of the play signified life, moves to the forefront filled with children's shoes (reminding of the piles of shoes in the pictures of Auschwitz and other concentration camps). The generation is gone, the only thing that is left is the shredded fragments of speech: 'Borya was stressed out. He was beside himself with worry....'; 'the head physician at Grauerman maternity hospital was a certain Boris Lvovich, who was their relative', 'the sound of songs already died out, leaving their traces on the face, - mournful in the beginning and cheerful in the end' - and a baby boy would be born...

The second part is devoted to the topic that is seemingly unrelated to the first - to Shostakovich, who appears as a boy attached to the leg of a huge four-meter doll. The doll looks like a solid and imposing lady (it is not without reason that the accompanying music is sung by popular Soviet singer Ludmila Zykina). Formal, carefully selected clothes show that this woman belongs to the so-called nomenklatura or the state bureaucracy, while the boy, resembling Shostakovich's picture in sieged Leningrad, given as a long shot, transfigures into Shostakovich in the close-up. Thus, the mode of 
relationship is set: a mother and a little child who is always about to dart off. The eye of the Mother, who has several assistants, sinister puppet masters dressed in black, would find the runaway child hiding in the grand-piano. She would use electric saws to mutilate the instrument, she would boast her service gun, chasing Akhmatova, Meyerhold, Mayakovsky, Mikhoels, Babel, Tukhachevsky, and Shostakovich, and shooting at them. She would only wound Shostakovich to finish him off later. She would finish him off by her care and motherly love: by piercing him with the help of a medal pin. She would make him kiss her gigantic regal hand, which looks as if it is separated from her body. She would kill him the same way as mothers accidentally suffocate their babies while sleeping and would go on to say that she did love him.

In the finale, the tenderest lines of Robert Burns ' 0 , wert thou in the cauld blast' are sung not in the form of a bard song, popular in Russia, but as a solemn choral and the verb 'to reign' acquires a sinister meaning, when the doll impersonating the power of the state and the Communist Party simply covers the boy (whose body seems to be as lifeless as his soul) as if devouring him. Did the artist really exist? Shostakovich's will and passion are depicted through montage: metal grand-pianos hid behind the improvised curtain are rolled to the forefront. The famous 'invasion theme' from the first movement of the Seventh Symphony accompanies the 'battle' of seven grand pianos: the sounds of metal mingle with the sounds of the orchestra. This is

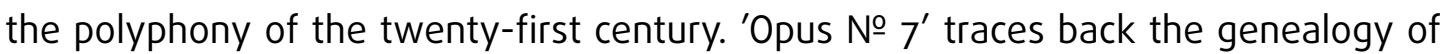
modernity, in which anybody can be crushed by the state machine, Soviet or Nazi.

Dmitry Krymov's theatre is a manifestation of modern culture articulated as postdramatic art. 'In postdramatic theatrical practice... different genres are combined in a performance (dance, narrative theatre, performance, etc.)' $([16], 174)$. Postdramatic theatre is closely connected to the avant-garde practices: this theatre is no longer text-centred; it distances itself from mimesis and questions the role of the actor as the central character of theatrical synthesis. According to Lehmann, who created the theory of postdramatic theatre, 'the actor of postdramatic theatre is often no longer the actor of a role but a performer offering his/her presence on stage for contemplation...For performance, just as for postdramatic theatre, 'liveness' comes to the fore, highlighting the provocative presence of the human being rather than the embodiment of a figure'. ([16], 174).

Lehmann describes the evolution of classical theatre towards post-drama by pointing out that 'postdramatic drama' is no longer centred around the 'story' but focuses on the 'game' ([16], 174). Postdramatic theatre uses montage principles of text organization in several ways. Montage draws together diverse arts, which join their individual 
voices to create the symphony of theatrical performance. Montage also brings to light the hidden links between different episodes and objects, thus creating an integrated associative field. Phrases, objects, and musical themes alike can serve as units of montage. For example, in Vladimir Pankov's staging of 'Zoyka's Flat', musical montage plays a key role: one of the characters shrieks 'in a chromatic scale', another plays the violin and yet another, the piano. The characters' vocal repertoir is also wide, starting from the lyrical song 'My beauty, do not sing for me' to the folk dancing tune 'The moon is shining brightly'. Vladimir Pankov's faithful version of the literary source makes full use of the music, which not only helps to describe characters and to recreate the atmosphere of a Moscow flat of the NEP period but also organizes all other elements of theatrical synthesis: for example, the logic of musical canons and progressions is reflected in the doubling and trebling of characters (two Anna Vadimovnas, two Manushkas, two Lisankas, two sewers, two cutters, two Mymras, two Madam Ivanovas, Agnessa Ferapontovnas, and three Ametistovs). The counterpoint and the basis of the polyphonic space is created by combining the classical harmony of the former aristocrats, whose ancestors lived in Ostozhenka street, the heart of the old Moscow, since 1625 (Obolyaninov), and the atonal music of the new world - the disturbing and aggressive sounds of the metal saw, heavy pounding on the backs of steel bunk beds, and so on. The cantilena of the song 'In Paris' composed by Artem Kim creates a stark contrast to the rigid structure constructed by the art director with its plank bunk bed as if predicting the fate of inhabitants of the 'haunted flat'. The dream about Paris, 'where my beloved is', would soon be replaced by the reality of a forced-labour camp, and the image of the beloved, by a certain 'Marusya Belova' from the song of sewing machine operators 'Soviet Lesbian Song'.

\section{Conclusion}

In the course of its development, montage was transformed from a technical term or technique into a fundamental concept and a method of artistic culture. When an artist faces discreteness or clear distinctiveness of elements or intentionally creates this discreteness of constituent elements, he has to select and re-assemble these elements, establishing the principles of their combination. Thus, montage is a characteristic of artistic vision, corresponding to the process of constructing a sequence of events, assemblage of objects and actions on the basis of their similarities and differences, expected or spontaneous reactions. Montage as a meaning-generating 
structure was created by the avant-garde, which was orientated towards the pragmatics of the text. Avant-gardist art required both the artist and the recipient to be active. Eisenstein's theory of montage was determined by these new goals of art to exercise direct emotional influence over the audience. The montage principle discovered by the avant-garde in the early twentieth century continues to be applied in modern artistic practices.

\section{References}

[1] Bagrov, P. 2010. "Sovetskiy Kinoavangard na Plenke i na Bumage" [Soviet AvantGarde on Tape and on Paper]. Seans. Retrieved from: http://seance.ru/blog/ bagrov-kinoavantgarde/

[2] Benjamin, W. 1996. "Proizvedeniye iskusstva v epokhu yego tekhnicheskoy vosproizvodimosti" [The Work of Art in The Age of Mechanical Reproduction]. In Izbrannyye esse. Moscow: Aspekt Press.

[3] Bulgakova, O. L. 1998. "Montazh - v teatral'noy laboratorii 20-kh Godov" [Montage in the Theatre Laboratory of the 1920s]. In Montazh: literatura, iskusstvo, teatr, kino, edited by M. Yampolsky. Moscow: Nauka.

[4] Burenina-Petrova, O.D. 2014. Tsirk v prostranstve kul'tury [Circus in the Space of Culture]. Moscow: Novoe literaturnoye obozrenie.

[5] Burger, P. 2014. Teoriya avangarda [Theory of the Avant-Garde]. Moscow: V-A-CPress.

[6] Canudo, R. 1988. "Manifest semi iskusstv" [Manifesto of Seven Arts] In Iz Istorii Frantsuzskoy Kinomysli: Nemoye Kino 1911-1933 gg., edited by. M. B. Yampolsky. Moscow: Iskusstvo.

[7] Deleuze, G. 2004. Kino [Cinema]. Moscow: Ad Marginem.

[8] Eisenstein, S.M. 1964. Izbrannyye raboty $v 6$ tomakh [Selected Works in 6 Volumes]. Vol. 2. Moscow: Iskusstvo.

[9] Eisenstein, S.M. 2002. "Dikkens, Griffit i my" [Dickens, Griffith, and Us]. In Psikhologicheskiye voprosy iskusstva, edited by E.Y. Basin. Moscow: Smysl.

[10] Eisenstein, S.M. 2016a. "Montazh 1938" [Montage 1938]. In Formal'nyy metod: Antologiya Russkogo Modernizma Sistemy. Vol. 1., edited by. S.A. Ushakin. Ekaterinburg, Moscow: Kabinetnyy uchenyy.

[11] Eisenstein, S.M. 2016b. "Montazh attraktsionov" [Montage of Attractions]. In Formal'nyy Metod: Antologiya russkogo Modernizma Sistemy. Vol. 1., edited by S.A. Ushakin. Ekaterinburg, Moscow: Kabinetnyy uchenyy. 
[12] Epstein, J. 1988. "Chuvstva" [The Senses]. In Iz istorii frantsuzskoy kinomysli: nemoye kino 1911-1933 gg., edited by M. B. Yampolsky. Moscow: Iskusstvo.

[13] Fomenko, A. 2007. Montozh, faktografiya, epos: Proizvodstvennoye dvizheniye $i$ fotografiya [Montage, Factography, Epic: Production Movement and Photography]. St. Petersburg: Publishing House of St.Petersburg University.

[14] Ivanov, V. V. 1988. "Montazh kak printsip postroyeniya v kul'ture pervoy poloviny 20 veka" [Montage as an Organizing Principle in the Culture of the First Half of the 2oth Century]. In Montazh: literatura, iskusstvo, teatr, kino, edited by M. Yampolsky. Moscow: Nauka.

[15] Kukulin, I. 2015. Mashiny zashumevshego vremeni: kak sovetskiy montazh stal metodom neofitsial'noy kul'tury [Machines of the Noise of Time: How the Soviet Montage Turned into a Method of Unofficial Culture]. Moscow: Novoe literaturnoye obozrenie.

[16] Lehmann H.-T. 2013. Postdramaticheskiy teatr [Postdramatic Theatre]. Moscow: ABCdesign.

[17] Lotman Yu. M. and Yu. G. Tsiv'yan 1994. Dialog s ekranom [Dialogue with the Screen]. Tallinn: Alexandra.

[18] MacKay J. 2017. "The Truth about Kino-Pravda, or Censorship as a Productive Force." KinoKultura. Retrieved from: http://www.kinokultura.com/2017/issue55.shtml

[19] Malevich, K. O. "Novykh sistemakh v iskusstve" [On New Systems in Art]. Retrieved from: http://www.k-malevich.ru/works/tom1/index36.html

[20] Platt, K.M. F. 2016. "Sergey Eyzenshteyn: Montazh vrazrez" [Sergey Eisenstein: Vertical Montage]. In Formal'nyy Metod: Antologiya Russkogo Modernizma Sistemy. Vol. 1., edited by S.A. Ushakin, 260-282. Ekaterinburg, Moscow: Kabinetnyy uchenyy.

[21] Samutina, N. 2012. "Ranneye Kino kak teoriya nastoyashchego" [Early Cinema as the Theory of the Present]. Kinovedcheskiye zapiski. Retrieved from: http://www. kinozapiski.ru/data/home/articles/attache/5-34.pdf

[22] Samutina, N. 2014. "FAQ: Kino attraktsionov: 8 faktov ob osobennostyakh rannego kino 19 - nachala 20 veka" [FAQ: Cinema of Attractions: Eight Facts about the Early Cinema of the 19th and Early 2oth Century]. Project 'PostNauka'. Retrieved from: https://postnauka.ru/faq/27805

[23] Scherbenok, A. 2012. "Dziga Vertov: dialektika kinoveshchi" [Dziga Vertov: Dialectic of Cine-Object]. Iskusstvo kino. Retrieved from: http://kinoart.ru/archive/2012/01/ dziga-vertov-dialektika-kinoveshi

[24] Shapir, M. 1990. "Chto Takoye Avangard?" [What is the Avant-Garde?]. Daugava, 3. 
[25] Tsivyan, Y. G. 1988. «Chelovek s kinoapparatom» "Dzigi Vertova. K rasshifrovke montazhnogo teksta" [Dziga Vertov's 'Man with a Movie Camera'. On Deciphering of the Montage Text]. In Montazh: literatura, iskusstvo, teatr, kino, edited by M. Yampolsky. Moscow: Nauka.

[26] Vertov, D. 1966. Stat'i, dnevniki, zamysly [Articles, Diaries, Thoughts]. Moscow.

[27] Yampolsky, M. B. 1988. Iz istorii frantsuzskoy kinomysli: Nemoye Kino 1911-1933 gg. Moscow: Iskusstvo. 